\title{
THIRTY-THIRD ANNUAL LIST OF PAPERS
}

\author{
READ BEFORE THE AMERICAN MATHEMATICAL SOCIETY AND \\ SUBSEQUENTLY PUBLISHED, INCLUDING REFERENCES \\ TO THE PLACES OF PUBLICATION
}

ADAMs, C. R. The general theory of a class of linear partial $q$-difference equations. Read Dec. 28, 1923. Transactions of this Society, vol. 26, No. 3, pp. 283-312; July, 1924.

Allen, E. F. The jacobian of a contact transformation. Read (Southwestern Section) Dec. 1, 1923. This Bulletin, vol. 30, No. 7, pp. 335-338; July, 1924.

Archibald, R. C. Mathematicians and music. Read Sept. 6, 1923. American Mathematical Monthly, vol. 31, No. 1, pp. 1-25; Jan., 1924.

BARNETT, J. A. On a class of invariant subgroups of the conformal and projective groups is function space. Read April 14, 1923. American Journal of Mathematics, vol. 46, No. 8, pp. 201-214; July, 1924.

Bateman, H. On some solutions of Laplace's equation. Read (San Francisco Section) Sept. 18, 1923. Messenger of Mathematics, vol. 54, No. 2, pp. 28-32; June, 1924.

BeLL E. T. A class of numbers connected with partitions. Read (San Francisco Section) April 7, 1923. American Journal of Mathematics, vol. 45, No. 2, pp. 73-82; April, 1923.

— On class number relations for bilinear forms in four variables. Read (San Francisco Section) April 7, 1923. American Journal of Mathematics, vol. 45, No. 4, pp. 255-258; Oct., 1923.

Umbral symmetric functions and algebraic analogues of the Bernoullian and Eulerian numbers and functions. Read (San Francisco Section) Oct. 21, 1922. Mathematische Zeitschrift, vol. 19, Nos. 1-2, pp. 35-49; Dec., 1923.

- Note on total representations as sums of squares. Read (San Francisco Section) April 7, 1923. American Mathematical Monthly, vol 30, No. 8, pp. 441-442; Dec., 1923.

- Extended class number relations. Read Dec. 27, 1922. Giornale di Matematiche, vol. 61, pp. 213-228; July-Dec., 1923.

- The numbers of representations of integers in certain forms $a x^{2}+b y^{2}+c z^{2}$. Read (San Francisco Section) April 5, 1924. American Mathematical Monthly, vol. 31, No. 3, pp. 126-131; March, 1924.

On certain quinary quadratic forms. Read (San Francisco Section) Dec. 22, 1923. This Bulletin, vol. 30, Nos. 3-4, pp. 127-130; March-April, 1924.

The class number relations implicit in the Disquisitiones Arithmeticae. Read (San Francisco Section) April 5, 1924. This Bulletin, vol. 30, Nos. 5-6, pp. 236-238; May-June, 1924.

Reductions of enumerations in homogeneous forms. Read (San Francisco Section) April 5, 1924 . This Bulletin, vol. 30, No. 7, pp. 345-351; July, 1924. 
BeLL, E. T. A new type of class number relations. Read (San Francisco Section) Oct. 25, 1924. Transactions of this Society, vol. 26, No. 4, pp. 446-450; Oct., 1924.

- Complete class number expansions for certain elliptic theta constants of the third degree. Read (San Francisco Section) April 5, 1924. This Bulletin, vol. 30, Nos. 9-10, pp.493-496; Nov.-Dec., 1924.

Bender, H. A. Determination of all the prime power groups containing only one invariant subgroup of every index which exceeds this prime number. Read April 18, 1924. Transactions of this Society, vol. 26, No. 4, pp. 427-434; Oct., 1924.

Bernstein, B. A. Complete sets of representations of two-element algebras. Read (San Francisco Section) 0ct. 21, 1922, and April 7, 1923. This Bulletin, vol. 30, Nos. 1-2, pp. 24-30; Jan.-Feb., 1924. A generalization of the syllogism. Read Sept. 7, 1923. This Bulletin, vol. 30, Nos. 3-4, pp. 125-127; March-April, 1924.

- Operations with respect to which the elements of a boolean algebra form a group. Read Sept. 7, 1923. Transactions of this Society, vol. 26, No. 2, pp. 171-175; April, 1924.

- Representation of three-element algebras. Read Dec. 27, 1923. American Journal of Mathematics, vol. 46, No. 2, pp. 110-116; April, 1924.

BuIss, G. A. Birational transformations simplifying singularities of algebraic curves. Read April 28, 1923. Transactions of this Society, vol. 24, No. 4, pp. 274-285; Dec., 1922.

BLumberg, $H$. On the characterization of the set of points of continuity. Read Dec. 30, 1920. Annals of Mathematics, (2), vol. 25, No. 2, pp. 118-122; Dec., 1923.

Brahana, H. R. A theorem concerning unit matrices with integer elements. Read April 13, 1923. Annals of Mathematics, (2), vol. 24, No. 3, pp. 265-270; March, 1923.

Brinkmann, H. W. Riemann spaces conformal to Einstein spaces. Read April 28, 1923. Mathematische Annalen, vol. 91, Nos. 3-4, pp. 269-278; 1924.

Brown, B. H. The equilong transformations of euclidean space. Read Dec. 27, 1922. Transactions of this Society, vol. 25, No. 4, pp. 469-484; 0ct., 1923.

Brown, E. W. An explanation of the gaps in the distribution of the asteroids according to their periods of revolution. Read March 1, 1924. Proceedings of the National Academy of Sciences, vol.10, No. 6, pp. 248-253; June, 1924.

Cajori, F., The history of notations of the calculus. Read (San Francisco Section) Oct. 22, 1921. Annals of Mathematics, (2), vol. 25, No. 1, pp. 1-46; Sept., 1923.

Did Pitiscus use the decimal point? Read (San Francisco Section) Sept. 18, 1923. Archivio di Storia della Scienza, vol. 4, No. 4, pp. 313-318; Dec., 1923.

Rahn's algebraic symbols. Read Dec. 29, 1923. American Mathematical Monthly, vol. 31, No. 2, pp. 65-71; Feb., 1924.

The growth of legend about Sir Isaac Newton. Read (San Francisco Section) Dec. 22, 1923. Science, new ser., vol. 59, No. 1531, pp. 390-392; May 2, 1924. 
CAMP, B. H. On a short method of least squares. Read Dec. 28, 1922. Annals of Mathematics, (2), vol. 24, No. 2, pp. 99-108; Dec., 1922.

CAMP, C. C. Expansions in terms of solutions of partial differential equations. Second paper: Multiple Birkhoff series. Read Dec. 29, 1922. Transactions of this Society, vol. 25 , No. 3, pp. 338-342; July, 1923.

Campbell, G. A. Mutual impedances of grounded circuits. Read Oct. 29, 1921. Bell System Technical Journal, vol. 2, No. 4, pp. 1-30; Oct., 1923.

Carlson, E. Extension of Bernstein's theorem to Sturm-Liouville sums. Read Sept. 7, 1922. Transactions of this Society, vol. 26, No. 2, pp. 230-240; April, 1924.

Carpenter, A. F. Flecnodal properties of a ruled surface. Read (San Francisco Section) April 8, 1922, and April 7, 1923. Tôhoku Mathematical Journal, vol. 23, Nos. 1-2, pp. 104-117; Aug., 1923.

Chittenden, E. W. Nuclear and hypernuclear points in the theory of abstract sets. Read (Southwestern Section) Dec. 1, 1923. This Bulletin, vol. 30, Nos. 9-10, pp. 511-519; Nov.-Dec., 1924.

Coble, A. B. The equation of the eighth degree. Read Dec. 28, 1923. This Bulletin, vol. 30, No. 7, pp. 301-313; July, 1924.

- Geometric aspects of the abelian modular functions of genus four. Read Dec. 31, 1919. American Journal of Mathematics, vol. 46, No. 3, pp. 143-192; July, 1924.

Cole, F. N. On simple groups of low order. Read Oct. 25, 1924. This Bulletin, vol. 30, Nos. 9-10, pp. 489-492, Nov.-Dec., 1924.

Copeland, L. P. Note on certain seminvariants of $n$-lines. Read April 14, 1922. Annals of Mathematics, (2), vol. 25, No. 2, pp. 137-141; Dec. 1923.

DAvis, H. T. An existence theorem for the characteristic numbers of a certain boundary value problem. Read April 15, 1922. Transactions of this Society, vol. 26, No. 1, pp. 1-16; Jan., 1924.

- Fractional operations as applied to a class of Volterra integral equations. Read April 13, 1923. American Journal of Mathematics, vol. 46, No.2, pp. 95-109; April, 1924.

Dickson, L. E. The rational linear algebras of maximum and minimum ranks. Read Dec. 29, 1922. Proceedings of the London Mathematical Society, (2), vol. 22, No. 2, pp. 143-160; Oct., 1923, and No. 3, pp. 161-162; Nov., 1923.

- A new simple theory of hypercomplex integers. Read Dec. 29, 1922. Journal de Mathématiques pures et appliquées, (9), vol. 2, No. 3, pp. 281-326; 1923.

- On the theory of numbers and generalized quaternions. Read Dec. 29, 1923. American Journal of Mathematics, vol. 46, No. 1, pp. 1-16; Jan., 1924.

- Algebras and their arithmetics. Read Dec. 28, 1923. This Bulletin, vol. 30, Nos. 5-6, pp. 247-257; May-June, 1924.

- Quadratic fields in which factorization is always unique. Read Dec. 29, 1923. This Bulletin, vol. 30, No. 7, pp. 328-334; July, 1924.

Dines, L. L. A theorem on the factorization of polynomials of a certain type. Read Sept. 7, 1923. Transactions of this Society, vol. 26, No. 1, pp. 17-24; Jan., 1924. 
Dines, L. L. Concerning a suggested and discarded generalization of the Weierstrass factorization theorem. Read Sept. 7, 1923. This Bulletin, vol. 30, Nos. 5-6, pp. 233-236; May-June, 1924.

DopD, E. L. The greatest and the least variate under general laws of error. Read April 28, 1923. Transactions of this Society, vol. 25, No. 4, pp. 525-539; Oct., 1923.

Douglas, J. Normal congruences and quadruply infinite systems of curves in space. Read Feb. 25, 1922, and April 28, 1923. Transactions of this Society, vol. 26, No. 1, pp. 68-100; Jan., 1924.

Dresden, A. Symmetric forms in $n$ variables. Read March 26, 1921, and Dec. 29, 1922. Annals of Mathematics, (2), vol. 24, No. 3, pp. 227-236; March, 1923 and vol. 25, No. 1, pp. 71-84; Sept., 1923. Brouwer's contributions to the foundations of mathematics. Read Dec. 29, 1923. This Bulletin, vol. 30, Nos. 1-2, pp. 31-40; Jan.Feb., 1924.

EDIngton, W. E. On an infinite system of non-abelian groups of order $n m^{n-1}$. Read Dec. 29, 1922. Annals of Mathematics, (2), vol. 25, No. 1, pp. 85-90; Sept., 1923.

Eisenhart, L. P. Space-time continua of perfect fluids in general relativity. Read 0ct. 27, 1923. Transactions of this Society, vol. 26, No. 2, pp. 205-220; April, 1924.

- Geometries of paths for which the equations of the paths admit a quadratic first integral. Read March 1, 1924. Transactions of this Society, vol. 26, No. 3, pp. 378-384; July, 1924.

Емсн, A. Some geometric applications of symmetric substitution groups. Read Feb. 24, 1923. American Journal of Mathematics, vol. 45, No. 3, pp. 192-207; July, 1923.

- Some problems of closure connected with the Geiser transformation. Read April 18, 1924. This Bulletin, vol. 30, Nos. 9-10, pp. 527-535; Nov.-Dec., 1924.

Evans, G. C. The dynamics of monopoly. Read Sept. 7, 1923. American Mathematical Monthly, vol. 31, No. 2, pp. 77-83; Feb., 1924.

Eversule, B. M. On convergence factors in triple series and the triple Fourier's series. Read April 14, 1922. Annals of Mathematics, (2), vol. 24, No. 2, pp. 141-166; Dec., 1922.

- The summability of the triple Fourier series at points of discontinuity of the function involved. Read Dec. 28, 1923. Transactions of this Society, vol. 26, No. 3, pp. 313-334; July, 1924.

Fischer, C. W. The Fredholm theory of Stieltjes integral equations. Read Feb. 25, 1922. Annals of Mathematics, (2), vol 25, No. 2, pp. 142-158; Dec., 1923.

Foster, M. C. Surfaces with orthogonal loci of the centers of geodesic curvature of an orthogonal system. Read April 28, 1923. This Bulletin, vol. 30, No. 7, pp. 322-327; July, 1924.

- Note on a special congruence. Read May 3, 1924. This Bulletin, vol. 30, Nos. 9-10, pp. 496-504; Nov.-Dec., 1924.

Franklin, P. Invariant sets of equations in Riemann space. Read April 28, 1923. Transactions of this Society, vol. 25, No. 4, pp. 485-500; Oct., 1923. 
Franklin, P. A qualitative definition of the potential functions. Read April 28, 1923. This Bulletin, vol. 30, Nos. 1-2, pp. 41-50; Jan.Feb., 1924.

Garabedian, C. A. Circular plates of constant or variable thickness. Read Feb. 24, 1923. Transactions of this Society, vol. 25, No. 3, pp. 343-398; July, 1923.

Plaques rectangulaires épaisses. Read March 1, 1924. Comptes Rendus de l'Académie des Sciences, vol. 178, No. 7, pp. 619-621; Feb. 11, 1924.

Glashan, J. S. C. The isodyadic quintic. Read Dec. 28, 1921. American Journal of Mathematics, vol. 45, No. 4, pp. 251-254; Oct., 1923.

- On the isodyadic septimic equations. Read Dec. 28, 1921. American Journal of Mathematics, vol. 46, No. 1, pp. 55-69; Jan., 1924.

Glens, 0. E. On the residues of figurate numbers. Read April 14, 1922, and Dec. 28, 1922. Annals of Mathematics, (2), vol. 25, No. 1, pp. 57-70; Sept., 1923.

- On the reduction of differential parameters in terms of finite sets, with remarks concerning differential invariants of analytic transformations. Read Sept. 9, 1921, Dec. 28, 1921, Feb. 24, 1923, April 28, 1923 and Sept. 7, 1923. American Journal of Mathematics, vol. 46, No. 1, pp. 37-54; Jan., 1924.

- The invariants of forms under the binary linear homogeneous group $G_{6}$ modulo 2. Read Dec. 28, 1923. This Bulletin, vol. 30, Nos. 3-4, pp. 131-139; March-April, 1924.

Gouwens, C. Invariants of the linear group modulo $\pi=p_{1}^{\lambda_{1}} p_{2}^{\lambda_{2}} \ldots p_{n}^{\lambda_{n}}$. Read April 19, 1924. Transactions of this Society, vol. 26, No.4, pp. 435-440; Oct., 1924.

Graustein, W. C. Representations of a complex point by pairs of ordered real points. Read Dec. 31, 1919. Transactions of this Society, vol. 24, No. 4, pp. 245-254; Dec., 1922.

- Spherical representation of conjugate systems and asymptotic lines. Read Feb. 25, 1922. Annals of Mathematics, (2), vol. 24, No. 2, pp. 89-98; Dec., 1922.

Determination of a surface by its curvatures and spherical representation. Read Dec. 27, 1922. American Journal of Mathematics, vol. 45, No. 4, pp. 294-314; Oct., 1923.

Applicability with preservation of both curvatures. Read Sept. 7, 1923. This Bulletin, vol. 30, Nos. 1-2, pp. 19-23; Jan.-Feb., 1924.

- Isometric $W$-surfaces. Read Sept. 7, 1923. Transactions of this Society, vol. 26, No. 2, pp. 176-204; April, 1924.

Graustein, W. C., and Koopman, B. 0. A necessary and sufficient condition that two surfaces be applicable. Read Dec. 27, 1922. Transactions of this Society, vol. 26, No. 3, pp. 369-372; July, 1924.

Hathaway, A. S. Gamma coefficients and series. Read Feb. 27, 1915. Proceedings of the Indiana Academy of Sciences, 1915, pp. 269-281.

HAzLETT, 0. C. A symbolic theory of formal modular covariants. Read Sept. 8, 1920, Dec. 28, 1921, and Dec. 28, 1922. Transactions of this Society, vol. 24, No. 4, pp. 286-311; Dec., 1922. 
Hedrick, E. R., Ingold, L., and Westfali, W. D. A. Theory of non-analytic functions of a complex variable. Read (Southwestern Section) Nov. 26, 1921. Journal de Mathématiques pures et appliquées, (9), vol. 2, No. 4, pp. 327-342; 1923.

Hille, E. A pythagorean functional equation. Read Oct. 28, 1922. Annals of Mathematics, (2), vol. 24, No. 2, pp. 175-180; Dec., 1922.

- An existence theorem. Read March 1, 1924. Transactions of this Society, vol. 26, No. 2, pp. 241-248; April, 1924.

Hiтchсоск, F. L. The coincident points of two algebraic transformations. Read Dec. 27, 1917. Journal of Mathematics and Physics of the Massachusetts Institute of Technology, vol. 3, No. 2, pp. 66-71; March, 1924.

Huntington, E. V. Sets of completely independent postulates for cyclic order. Read Dec. 27, 1916, Oct. 27, 1923, and Dec. 27, 1923. Proceedings of the National Academy of Sciences, vol. 10, No. 2, pp. 74-78; Feb., 1924.

A new set of postulates for betweenness, with proof of complete independence. Read Dec. 27, 1923. Transactions of this Society, vol. 26, No. 2, pp. 257-282; April, 1924.

Hutchinson, J. I. On a remarkable class of entire functions. Read April 28, 1923. Transactions of this Society, vol. 25, No. 3, pp. 325-332; July, 1923.

Ingold, L. See Hedrick, E. R.

JACKson, D. Note on an ambiguous case of approximation. Read Dec. 30, 1920. Transactions of this Society, vol. 25, No. 3, pp. 333-337; July, 1923.

- On approximation by functions of given continuity. Read April 14, 1923. Transactions of this Society, vol. 25, No. 3, pp. 449-458; July, 1923.

A generalized problem in weighted approximation. Read 0ct. 27, 1923, and Dec. 29, 1923. Transactions of this Society, vol. 26, No. 1, pp. 133-154; Jan., 1924.

The trigonometry of correlation. Read April 19, 1924. American Mathematical Monthly, vol. 31, No. 6, pp. 275-280; June, 1924.

- A symmetric coefficient of correlation for several variables. Read April 19, 1924. This Bulletin, vol. 30, Nos. 9-10, pp. 536-542; Nov.-Dec., 1924.

JAMEs, G. On the solution of algebraic equations with rational coef ficients. Read (San Francisco Section) April 5, 1924. American Mathematical Monthly, vol. 31, No. 6, pp. 283-287; June, 1924.

KellogG, O. D. Some properties of spherical curves, with applications to the gyroscope. Read April 28, 1923. Transactions of this Society, vol. 25, No. 4, pp. 501-524; Oct., 1923.

KIINE, J. R. Closed connected sets which remain connected upon the removal of certain connected subsets. Read Sept. 8, 1921. Fundamenta Mathematicae, vol. 5, pp. 3-10; 1924.

Concerning the division of the plane by continua. Read March 1, 1924. Proceedings of the National Academy of Sciences, vol. 10, No. 5, pp. 176-177; May, 1924.

Koopman, B. 0. See Graustein, W. C. 
LANE, E. P. A characterization of surfaces of translation. Read April 18, 1924. This Bulletin, vol. 30, Nos. 5-6, pp. 231-232; May-June, 1924.

LAREw, G. A. The Hilbert integral and Mayer fields for the problem of Mayer in the calculus of varations. Read Dec. 28, 1920. Transactions of this Society, vol. 26, No. 1, pp. 61-67; Jan., 1924.

LIPKA, J. On Ricci's coefficients of rotation. Read 0ct. 27, 1923. Journal of Mathematics and Physics of the Massachusetts Institute of Technology, vol. 3, No. 1, pp. 7-23; Jan., 1924.

MacDuffee, C. C. On covariants of linear algebras. Read Dec. 28, 1922. Transactions of this Society, vol. 26, No. 1, pp. 124-132; Jan., 1924.

Michal, A. D. Integro-differential invariants of one-paramete $r$ groups of Fredholm transformations. Read (Southwestern Section) Dec. 1, 1923. This Bulletin, vol. 30, No. 7, pp. 338-344; July, 1924.

MILLER, G. A. New applications of a fundamental theorem of substitution groups. Read Dec. 28, 1922. Annals of Mathematics, (2), vol. 25, No. 1, pp. 47-52; Sept., 1923.

- American mathematics during three quarters of a century. Read Dec. 28, 1923. Science, new ser., vol.59, No.1514, pp. 1-7; Jan. 4, 1924.

- Number of cycles of the same order in any given substitution group. Read Dec. 29, 1923. This Bulletin, vol. 30, Nos. 5-6, pp. 239-246; May-June, 1924.

Moore, C. N. Generalized limits in general analysis. Second paper. Read April 14, 1922. Transactions of this Society, vol. 25, No. 4, pp. 459-468; Oct., 1923.

Moore, R. L. An extension of the theorem that no countable point set is perfect. Read Dec. 29, 1923. Proceedings of the National Academy of Sciences, vol. 10, No. 5, pp. 168-170; May, 1924. Concerning the prime parts of certain continua which separate the plane. Read Dec. 28, 1923. Proceedings of the National Academy of Sciences, vol. 10, No. 5, pp. 170-175; May, 1924.

Concerning relatively uniform convergence. Read April 14, 1922. This Bulletin, vol. 30, Nos. 9-10, pp. 504-505; Nov.-Dec., 1924. Concerning the sum of a countable number of mutually exclusive continua in the plane. Read Sept. 7, 1923. Fundamenta Mathematicae, vol. 6, pp. 189-202; 1924.

- Concerning the common boundary of two domains. Read March 1, 1924. Fundamenta Mathematicae, vol. 6, pp. 208-213; 1924.

Morse, H. M. A fundamental class of geodesics on any closed surface of genus greater than one. Read Sept. 8, 1921. Transactions of this Society, vol. 26, No. 1, pp. 25-60; Jan., 1924.

MurRay, F. H. A type of differential system containing a parameter. Read Sept. 8, 1922. Transactions of this Society, vol. 25, No. 3, pp. 315-324; July, 1923.

The asymptotic expansion of the functions $W_{k, m}(z)$ of Whittaker. Read Feb. 24, 1923. American Journal of Mathematics, vol. 45, No. 3, pp. 186-191; July, 1923. 
Murray, F. H. Note on stability à la Poisson. Read Oct. 27, 1923. This Bulletin, vol. 30, Nos. 1-2, pp. 17-18; Jan.-Feb., 1924.

Nelson, C. A. The Riemann adjoints of completely integrable systems of partial differential equations. Read Feb. 24, 1923. American Journal of Mathematics, vol. 46, No. 2, pp. 117-130; April, 1924.

PólyA, G. On the mean-value theorem corresponding to a given linear homogeneous differental equation. Read Oct.27, 1923. Transactions of this Society, vol. 24, No. 4, pp. 312-324; Dec., 1922.

RAINich, G. Y. A new hind of representation of surfaces. Read Sept. 7, 1923. Proceedings of the National Academy of Sciences, vol. 9, No. 12, pp. 401-403; Dec., 1923.

Two-dimensional tensor analysis without coordinates. Read April 28, 1923. American Journal of Mathematics, vol. 46, No. 2, pp. 71-94; April, 1924.

Electrodynamics in the general relativity theory. Second note. Read Dec.27, 1923, and March 1, 1924. Proceedings of the National Academy of Sciences, vol. 10, No. 4, pp. 124-127; April, 1924.

- Second note: Electrodynamics in the general relativity theory. Read May 3, 1924. Proceedings of the National Academy of Sciences, vol. 10, No. 7, pp. 294-298; July, 1924.

RICE, L. H. A contribution to the generalization of a determinantal theorem of Frobenius. Read Feb. 24, 1923. Journal of Muthematics and Physics of the Massachusetts Institute of Technology, vol. 3, No. 2, pp. 118-126; March, 1924.

RICHaRDson, R. G. D. A new method in the equivalence of pairs of bilinear forms. Read Dec. 29, 1920. Transactions of this Society, vol. 26, No. 4, pp. 451-478; Oct., 1924.

- Relative extrema of pairs of quadratic and hermitian forms. Read Sept. 7, 1923. Transactions of this Society, vol. 26, No. 4, pp. 479-494; Oct., 1924.

RIDER, P. R. On the minimizing of a class of definite integrals. Read April 14, 1922. Annals of Mathematics, (2), vol. 24, No. 2, pp. 167-174; Dec., 1922.

The correlation between two variates one of which is normally distributed. Read April 19, 1924. American Mathematical Monthly, vol. 31, No. 5, pp. 227-231; May, 1924.

RIETz, H. L. On certain topics in the mathematical theory of statistics. Read April 18, 1924. This Bulletin, vol. 30, No. 8, pp. 417-453; Oct., 1924.

Ritr, J. F. Permutable rational functions. Read Feb. 24, 1923. Transactions of this Society, vol. 25, No. 3, pp. 399-448; July, 1923.

- Equivalent rational substitutions. Read March 1, 1924. Transactions of this Society, vol. 26, No. 2, pp. 221-229; April, 1924. Analytic functions and periodicity. Read May 3, 1924. This Bulletin, vol. 30, No. 8, pp. 406-409; 0ct., 1924.

RUTLEDGE, G. Maclaurin expansion of the interpolation polynomial determined by $2 n+1$ evenly spaced points. Read Feb. 24, 1923. Transactions of this Society, vol. 26, No. 1, pp. 113-123; Jan., 1924.

Shoнat, J. A. The theory of closure of Tchebycheff polynomials for an infinite interval. Read Dec. 29, 1923. This Bulletin, vol. 30, Nos. 9-10, pp. 505-510; Nov.-Dec., 1924. 
Silverman, L. L. The equivalence of certain regular transformations. Read April 26, 1919. Transactions of this Society, vol. 26, No.1, pp. 101-112; Jan., 1924.

Syarl, L. L. Some theorems on triple limits. Read (San Francisco Section) May 22, 1914. Tôhoku Mathematical Journal, vol. 23, Nos. 1-2, pp. 163-166; Aug., 1923.

SNYDER, V. Problems in involutorial transformations of space. Read Dec. 28, 1923. This Bulletin, vol. 30, Nos. 3-4, pp. 101-124; March-April, 1924.

STEED, D. V. The hyperspace generalizations of the lines on the cubic surface. Read (San Francisco Section) April 9, 1921. University of California Publications in Mathematics, vol. 1, No. 20, pp. 425-443; May 17, 1924.

Stone, M. H. An unusual type of expansion problem. Read March 1, 1924. Transactions of this Society, vol. 26, No. 3, pp. 335-355; July, 1924.

STOUFFer, E. B. On the independence of principal minors of determinants. Read April 14, 1922, and Dec. 1, 1923. Transactions of this Society, vol. 26, No. 3, pp. 356-368; July, 1924.

TAYLOR, J. S. A statistical theory of depreciation Read. Dec.27, 1923. Journal of the American Statistical Association, vol. 18, No. 144, pp. 1010-1023; Dec., 1923.

Theory of testimony. First paper: A single witness. Read Dec. 28, 1923. Journal of Mathematics and Physics of the Massachusetts Institute of Technology, vol. 3, No. 3, pp. 162-173; April, 1924.

Thomas, T. Y. See Veblen, 0.

VANDIVER, H. S. Methods for finding factors of large integers. Read Dec. 28, 1920, and Sept. 7, 1923. This Bulletin, vol. 30, Nos. 9-10, pp. 542-553; Nov.-Dec., 1924.

VAN DE WALLE, W. E. On the complete independence of the postulates for betweenness. Read March 1, 1924. Transactions of this Society, vol. 26, No. 2, pp. 249-256; April, 1924.

VAN VLECK, E. B. Non-loxodromic substitutions and groups in $n$ dimensions. Read Sept. 5, 1916, and March 25, 1921. Transactions of this Society, vol. 24, No. 4, pp. 255-273; Dec., 1922.

Veblen, 0. The intersection numbers. Read April 24, 1920. Transactions of this Society, vol. 25, No. 4, pp. 540-550; Oct., 1923.

Veblen, 0., and Thomas, T. Y. The geometry of paths. Read 0ct.28, 1922, and April 28, 1923. Transactions of this Society, vol. 25, No. 4, pp. 551-608; Oct., 1923.

- Extensions of relative tensors. Read April 19, 1924. Transactions of this Society, vol. 26, No. 3, pp. 373-377; July, 1924.

WAHLIN, G.E. On the application of the theory of ideals to diophantine analysis. Read Dec. 29, 1923 . This Bulletin, vol. 30, Nos. 3-4, pp. 140-154; March-April, 1924.

WALSH, J. L. On the convergence of the Sturm-Liouville series. Read Dec. 28, 1920. Annals of Mathematics, (2), vol. 24, No. 2, pp. 109120; Dec., 1922.

On the location of the roots of polynomials. Read Dec. 27, 1922. This Bulletin, vol. 30, Nos. 1-2, pp. 51-62; Jall.-Feb., 1924. 
WALSH, J. L. On the expansion of analytic functions in series of polynomials. Read Dec. 27, 1923. Transactions of this Society, vol. 26, No. 2, pp. 155-170; April, 1924.

A generalization of evolutes. Read Sept. 7, 1923. Rendiconti del Circolo Matematico di Palermo, vol.48, No.1, pp.23-27; Jan.-April, 1924.

Wedderburn, J. H. M. Algebras which do not possess a finite basis. Read May 3, 1924. Transactions of this Society, vol. 26, No. 4, pp. 395-426; Oct., 1924.

WeIsNer, L. Group of a set of simultaneous algebraic equations. Read Dec. 27, 1923. This Bulletin, vol. 30, No. 7, pp. 314-316; July, 1924.

Westfall, W. D. A. See Hedrick, E. R.

Widder, D. V. A general mean-value theorem. Read May 3, 1924. Transactions of this Society, vol. 26, No. 3, pp.385-394; July, 1924.

Wiener, N. Note on a new type of summability. Read April 28, 1923. American Journal of Mathematics, vol. 45, No. 2, pp. 83-86; April, 1923.

Discontinuous boundary conditions and the Dirichlet problem. Read April 28, 1923. Transactions of this Society, vol. 25, No.3, pp. 307-314; July, 1923.

Note on the series $\Xi( \pm 1 / n)$. Read Dec. 27, 1922. Bulletin de l'Académie Polonaise des Sciences et des Lettres, Classe des Sciences mathématiques et naturelles, ser. A, 1923; pp. 87-90.

The quadratic variation of a function and its Fourier coefficients. Read Sept. 7, 1923. Journal of Mathematics and Physics of the Massachusetts Institute of Technology, vol. 3, No. 2, pp. 72-94; March, 1924.

The average value of a functional. Read Dec. 28, 1920. Proceedings of the London Mathematical Society, (2), vol. 22, No. 6, pp. '454-467; March, 1924.

Une condition nécessaire et suffisante pour le problème de Dirichlet. Read Dec. 29, 1923. Comptes Rendus de l'Académie des Sciences, vol. 178, No. 13, pp. 1050-1053; March 24, 1924.

The Dirichlet problem. Read Dec. 29, 1923. Journal of Mathematics and Physics of the Massachusetts Institute of Technology, vol. 3, No. 3, pp. 127-146; April, 1924.

Wilczynski, E. J. Differential properties of functions of a complex variable which are invariant under linear transformations. Read April 13, 1918. Journal de Mathématiques pures et appliquées, (9), vol. 2, pp. 1-51; 1923.

WILDER, R. L. On the dispersion sets of connected point-sets. Read Dec. 29, 1923. Fundamenta Mathematicae, vol. 6, pp. 214-228; 1924.

Williams, K. P. A uniqueness theorem for Legendre's and Hermite's polynomials. Read Oct. 25, 1924. Transactions of this Society, vol. 26, No. 4, pp. 441-445; Oct., 1924.

Zeldin, S. D. On the quadratic ternary partial differential equations admitting Lie groups of orders four and five. Read April 28, 1923. Journal of Mathematics and Physics of the Massachusetts Institute of Technology, vol. 2, No. 4, pp. 234-254; Dec., 1923. 